\title{
BUYA HAMKA DAN PANDANGANNYA TENTANG IJTIHAD
}

\author{
Ali Wardana \\ alinadiahaikal@yahoo.co.id \\ (Dosen Fakultas Agama Islam, Universitas Muhammadiyah Tangerang )
}

\begin{abstract}
Abstrak:
Kemajuan peradaban dan ilmu pengetahuan dalam Islam seperti dalam bidang Ilmu Ushul Fiqh, Fiqh, Ilmu Tafsir, Ilmu Tasawuf dan lain-lain adalah berpangkal dari terbukanya pintu ijtihad. Begitu juga dengan hadirnya ulama-ulama besar yang telah mendirikan empat mazhab figh dalam Islam adalah juga bersumber dari adanya kebebasan berijtihad itu sendiri. Buya Hamka, sebagai seorang ulama cendikiawan adalah salah satu penganjur dari kebebasan menyatakan hasil pemikiran yang matang dan diyakini (berijtihad) dengan berpegang kepada syarat-syaratnya, yaitu jangan keluar dari garis adab dan sopan walaupun yang benar yang akan diterangkan. Dan seyaogianya pula ia sanggup mempertahankan keyakinan dan hujjahnya, luas pandangannya serta mengetahui hakikat perkara yang ditulisnya.
\end{abstract}

\section{Kata Kunci: Buya Hamka, Pandangan, Ijtihad.}

\section{A. Pendahuluan}

Ajaran Islam yang diturunkan oleh Allah kepada Nabi Muhammad SAW adalah bersifat universal, tidak terbatas oleh waktu dan tempat, tetapi juga cocok dan sesuai untuk segala zaman. Karena itu, ajaran Islam dapat berlaku untuk seluruh umat manusia, kapan pun dan dimana pun mereka berada. Keuniversalan ajaran Islam dapat dipahami karena Islam yang dibawa oleh nabi dan rasul terakhir, Nabi Muhammad SAW yang hidup pada pertengahan abad ke $6 \mathrm{M}$, diutus oleh Allah sebagai pembawa rahmat bagi seisi alam semesta. Kitab suci yang diturunkan Allah kepadanya adalah al-Qur'an, dan kitab suci ini sekaligus merupakan sumber pokok dari ajaran agama Islam.

Mayoritas dari hukum-hukum yang terdapat dalam al-Qur'an adalah bersifat global, tidak terinci, atau hanya terbatas pada penjelasan-penjelasan dasar-dasar umum dan kaidah-kaidah yang menyeluruh. Karena itu, al-Qur'an merupakan undang-undang abadi bagi umat manusia, tidak disimpangkan, diganti, dilompati, dan tidak pula tercecer ketika diterapkan. ${ }^{1}$ Al-Qur'an sebagai kitab suci umat Islam senantiasa relevan untuk masa-masa keislaman yang berbeda. Karena demikian, al-Qur'an memerlukan penjelasan (tabyin dan tafsir) dari sunnah. Al-Qur'an sangat butuh terhadap Sunnah Nabi SAW. ketimbang kebutuhan sunnah terhadap al-Qur'an. Sunnah merupakan kunci dari al-Qur'an karena dengan sunnah seseorang akan mendapatkan petunjuk untuk mengetahui hukum-hukum alQur'an, menyingkap hakikatnya, dan menjelaskan maksud-maksudnya. ${ }^{2}$

Sunnah Nabi SAW memiliki kedudukan yang istimewa terhadap alQur'an dalam tasyri'. Semua respon Nabi Muhammd SAW. terhadap suatu masalah, baik melalui perkataan, perbuatan, ataupun pengakuannya menjadi sumber pokok kedua dari ajaran Islam setelah al-Qur'an.

\footnotetext{
${ }^{1}$ Wahbah az-Zuhaili, al-Qur'an, Paradigma Hukum dan Peradaban, terjemahan Muhammad Lukman Hakim dan Muhammad Fuad Hariri, (Surabaya: Risalah Gusti, 1995), hlm.49.

${ }^{2}$ Ibid. hlm.70
} 
Kedua sumber pokok ajaran Islam (alQur'an dan Sunnah) ini secara kuantitatif tidak akan bertambah lagi setelah wafatnya Nabi SAW. Karena itu dengan wafatnya Nabi Muhammad SAW maka ajaran Islam yang diturunkan oleh Allah SWT telah menjadi sempurna. Di sisi lain, problem dan permasalah kehidupan manusia semakin hari kian bertambah banyak dan semakin kompleks dan beragam, sehingga tidak dapat lagi dicover secara eksplisit oleh kedua sumber pokok ajaran Islam tersebut.

Kedua sumber pokok ajaran Islam (al-Qur'an dan Sunnah) beserta isi-isi yang dikandungnya tetap relevan sepanjang zaman (shalih likulli zaman wa makan) dalam menjawab setiap permasalahan yang ada walaupun teks keagamaan (an-nushus as-syar'iyah) secara kuantitatif tidak bertambah lagi. Di sini dipahami bahwa Allah SWT tidak menjadikan al-Qur'an dan sunnah dalam bentuk baku, final dan siap pakai, yang digunakan untuk menjawab secara rinci semua permasalahan-permasalahan yang ada baik yang telah, sedang, atau pun akan terjadi. Sebab jika demikian, ajaran Islam akan cepat usang dan akan kehilangan elan vitalnya untuk merespons akan segala problem-problem kemanusiaan yang senantiasa berkembang dengan sangat cepat.

Banyak sekali permasalahan dan kondisi yang baru yang menuntut akan ijtihad baru. Permasalahan baru tersebut tidak ditemukan dalam hukum fiqh yang termuat dalam kitab-kitab fiqh seperti transaksi akibat perubahan cuaca daratan, lautan, dan udara baru. Transaksi dalam asuransi, bagi hasil, jual beli terhadap sesuatu di masa yang akan datang, apakah dengan harga pasar atau nilai mata uang. Hal lain misalnya, sewa menyewa dalam jangka panjang, atau transaksi baru karena adanya peraturan baru, dan transaksi yang disertai dengan adanya keuntungan salah satu pihak. Pada dataran inilah sangat dirasa akan perlunya para ulama untuk berijtihad.

\section{B. Konsep Ijtihad dalam Islam}

Semangat ijtihad telah diawali sejak Nabi Muhammad SAW. Para ulama sepakat menyatakan bahwa harus bagi Nabi SAW melakukan ijtihad terutama pada permasalahan-permasalahan yang berkaitan dengan kemaslahatan dunia (masalih ad-dunya) dan mengatur peperangan (tadbir al-hurub) serta lain sebagainya. Para sahabat juga melakukan ijtihad meskipun Nabi SAW masih hidup, akan tetapi para sahabat mengkonfirmasi langsung hasil ijtihadnya kepada Nabi. Salah satu contoh ijtihad Nabi adalah tentang ketentuan azan. Lahirnya ketentuan azan ini bermula dari hasil diskusi antara beberapa orang sahabat. Sebagian sahabat berpendapat bahwa untuk memanggil orang shalat, sebaiknya menggunakan lonceng sebagaimana longceng gereja (Nasrani). Sebagian sahabat yang lain menganjurkan untuk menggunakan terompet seperti sinagog-sinagog (Yahudi). Kemudian Umar bin Khattab bertanya kepada Nabi SAW: "Mengapa Tuan tidak mengutus seseorang untuk mengajak shalat?" Nabi SAW kemudian bersabda, "Hai Bilal, berdirilah dan ajaklah shalat!". 3

Terminologi ijtihad dapat ditemukan hampir diseluruh kitab-kitab ushul fiqh dan ia tetap merupakan satu tema yang akan tetap relevan dengan konteks zaman. Ijtihad selalu didefinisikan oleh para ahlinya, mulai dari ulama klasik sampai moderen. Dalam artian etimologi, kata ijtihad berasal dari kata jahada (جه), artinya "mencurahkan segala kemampuan"

${ }^{3}$ Abd al-Jalil 'Isa, Ijtihad ar-Rasul Salla Allah 'alaihi Wasallam, (Beirut: Dar al-Bayyan, 1969), hlm. 173-174. 
atau "menanggung beban kesulitan". ${ }^{4}$ Oleh karena itu adalah suatu kekeliruan yang sangat mendasar apabila umat Islam menempatkan konsep "ijtihad" pada sesuatu yang mudah atau ringan. Sedangkan bentuk lain dari ijtihad adalah "al-jahdu" yang berarti "daya upaya" (الطاقة) dan "beban kesulitan" (المشقة), sehingga kata "ijtihad" juga dapat berarti bersungguh-sungguh menggunakan daya upaya dan menanggung beban pikiran. Secara implisit, pengertian ini menunjukkan bahwa ijtihad itu menuntut para pelakunya (mujtahidin) untuk bersungguh-sungguh dalam segalanya, baik dari segi fisik maupun psikisnya, terutama kapasitas keilmuannya. Oleh karena itu, sangat wajar dan dapat dimaklumi jika para ulama menetapkan beberapa syarat yang cukup selektif bagi seorang mujtahid. Seperti berilmu dengan kitab Allah (al-Qur'an), berilmu dengan sunnah yang berkaitan dengan hukum, berilmu dengan masalah nasekh dan mansukh, memahami persoalan-persoalan ijma', memahami masalah qiyas, memahami ilmu tata bahasa Arab, dan menguasai ilmu ushul fiqh. ${ }^{6}$

Seorang mujtahid dalam berijtihad harus menjaga dasar-dasar Islam dan pokok-pokoknya yang umum, seperti menuntut kebenaran dan keadilan, mengharamkan kezaliman, persamaan dalam hak asasi, kesaksian dan sama di depan hukum. Seorang mujtahid dalam melakukan ijtihad juga harus menjaga kemaslahatan, menolak kemafsadatan (kerusakan), adat yang benar dan tidak

${ }^{4}$ Jamaluddin Muhammad ibn Mundzir, Lisan al-Arab, (Mesir: Dar al-Mishriyyah at-Ta'lif wa atTarjamah, t.t.), Juz III, hlm.107-109.

${ }^{5}$ Saifuddin Abi Hasan Ali bin Muhammad alAmidi, Mustaha Shul fi Ilmi Ushul, (Beirut: Dar alKutub al-Ilmiyah, 2002), hlm.238.

${ }^{6}$ Wahbah az-Zuhaili, al-Wajiz fi Ushul Fiqh Islami,(Beirut: Dar al-Khair, 2006), Juz.II, hlm. 287-291. bertentangan dengan nash-nash syara'. Begitu juga seorang mujtahid harus menolak ketentuan-ketentuan syubhat dan menjaga kaidah syar'iyyah secara umum (kulliyah) seperti kaidah: "kesulitan dapat menarik kemudahan", "darurat dapat membolehkan sesuatu yang dilarang”, "darurat ditentukan dengan kadarnya", "kebutuhan umum atau khusus golongan tertentu dapat menempati kriteria darurat", "melakukan muamalat yang utama dan menjauhi yang jelek", "yakin tidak dapat dihilangkan dengan bukti yang meragukan", "bahaya itu dihilangkan", "adat kebiasaan menempati hukum", "segala persoalan dikaitkan dengan tujuannya", dan lain sebagainya.

Masih berkaitan dengan pengertian ijtihad secara etimologi, sebagian ulama mengidentikkan kata ijtihad dengan kata istinbath. Bahkan menurut pengertian yang lazim ditemukan dalam kajian ilmu ushul fiqh, ijtihad sering disamakan dengan istinbath. Kata istinbath berasal dari kata nabth yang berarti "air yang memancar" atau "air yang mula memancar dari sumur yang digali". Secara etimologi istinbath berarti mengeluarkan sesuatu dari persembuyiannya. Karena sebagian ulama menganggap bahwa ijtihad itu sama dengan istinbath maka ijtihad didefinisikan dengan menggali hukum syara' yang belum ditegaskan secara langsung oleh nash al-Qur'an dan Sunnah.

Para ulama ushul fiqh dari masa klasik hingga moderen mendefinisikan ijtihad secara terminologi dengan redaksi yang beragam. Pada masa klasik dan pertengahan, Al-Qadhi Baidawi (w.685H) misalnya mendefinisikan ijtihad dengan "mencurahkan kemampuan maksimal dalam upaya menggali hukum-hukum syara,."7 Ibn Humam (w.861H)

${ }^{7}$ Jamaluddin Abd Rahman al-Asnawi, Syarh al-Asnawi Syarh Minhaj al-Wusul fi Ilmi Ushul, (Mesir: Muhammad Ali Subaih, t.t.), hlm.191. 
mendefinisikan ijtihad sebagai "pengerahan kemampuan fuqaha dalam menggali hukum syariat yang bersifat dzanni". ${ }^{8}$ Sedangkan Imam asy-Syaukani (w.1250H) mendefinisikan ijtihad dengan "pengerahan kemampuan dalam memperoleh hukum syariat 'amaliah dengan cara istinbath". 9 Para ahli ushul fiqh moderen seperti Abu Zahrah mendefinisikan ijtihad dengan "pengerahan kemampuan fuqaha dalam menggali hukum 'amaliah dari dalil-dalil yang rinci". ${ }^{10}$

Dari berbagai macam pengertian ijtihad yang dikemukakan oleh para ulama di atas maka dapat diambil suatu pemahaman bahwa ijtihad itu adalah pengerahan kemampuan secara maksimal oleh fuqaha dalam upaya menggali hukumhukum syara' yang bersifat dzanni dari dalil-dalil yang rinci. Berdasarkan kepada pengertian ijtihad ini mengisyaratkan bahwa ijtihad itu hanya berlaku dalam lapangan fiqh semata. Sedangkan ijtihad yang keluar dari konteks pengertian ijtihad tersebut tidak disebut sebagai ijtihad dalam pandangan fiqh. Berdasarkan pernyataan ini maka sangat wajar sekali jika ada para ulama dengan tegas menyatakan bahwa kegiatan ijtihad itu dibatasi pada lapangan fiqh dan hanya dilakukan oleh fuqaha semata.

Munculnya gerakan pembaharuan yang dipelopori pertama kali oleh Ibn Taimiyyah, tokoh yang terkenal dengan sebutan mujaddid al-Islam, berpandangan adanya kemungkinan melakukan ijtihad di luar bidang fiqh (hukum Islam), bahkan tidak menutup kemungkinan melakukan ijtihad dalam bidang aqidah dan tasawuf.

${ }^{8}$ Ibn al-Humam, al-Tahrir,(Mesir: Mustafa al-Babi al-Halabi wa Awladuhu, 1351), hlm.523.

${ }^{9}$ Muhammad asy-Syaukani, Irsyad al-Fuhul, (Beirut: Dar al-Ihya at-Turas al-Arabi, t.t.), hlm. 250 .

${ }^{10}$ Muhammad Abu Zahrah, Ushul Fiqh, (Beirut; Dar al-Fikr, 1976), hlm.379.
Dalam salah satu karyanya tentang tema politik, Ibn Taimiyyah memberi peluang besar bagi kemungkinan munculnya ijtihad pada aspek politik. ${ }^{11}$ Munculnya gerakangerakan pembaharuan dalam Islam pada umumnya terjadi setelah munculnya "pemasungan" ijtihad. Penggunaan kata ijtihad dalam gerakan pembaharuan mengalami pengembangan, tidak hanya pada fiqh, tetapi mencakup aspek-aspek lain, seperti filsafat, akhlak, teologi bahkan kebudayaan. Perluasan pemakaian ijtihad ini didasari oleh munculnya kesadaran historis pada awal Islam, yang pada waktu itu pemakaian kata ijtihad lebih universal.

Keberhasilan umat Islam dalam berbagai aspek pada periode awal disebabkan oleh keberanian para sahabat melakukan dinamisasi ajaran Islam secara kaffah (menyeluruh) dengan konsep ijtihad yang mereka pakai. Salah satu faktor dari keberhasilan Umar bin Khattab dalam membangun peradaban Islam secara gemilang adalah karena ia berani melakukan ijtihad dalam berbagai bidang. Tanpa keberanian pemakaian ijtihad untuk semua aspek kehidupan kemungkinan Umar tidak akan berhasil dengan baik dalam membangun negara Islam. ${ }^{12}$

Pemakaian kata "ijtihad" pada awalawal Islam tidak sesempit ketika terjadinya "isu" penutupan pintu ijtihad. Ijtihad merupakan suatu keharusan dalam Islam bahkan ia juga menjadi salah satu asal dari asal syariat. Pintu ijtihad sebenarnya selalu terbuka untuk seseorang yang ahli terhadap masalah-masalah ijtihad itu melalui kemampuan akal yang dimilikinya, kemampuan bahasa dan syariat, dengan meng-istinbath-kan hukum-hukum dari petunjuk Allah dan sumbersumbernya.Pembatasan bidang ijtihad pada

${ }^{11}$ Ahmad Kholid, Melacak Sejarah Metodologi Ijtihad, (Bandung: Sahifa, 2009), hlm.77.

${ }^{12}$ Ibid. hlm. 79. 
masalah-masalah yang tidak dinash atau ada nash, tetapi sifatnya memiliki indikasi dalil dzanni adalah suatu keharusan dalam hukum Islam. Sedangkan aspek aqidah, ibadat, akhlak dan ketentuan-ketentuan syariat yang sudah qath'i tidak lagi menjadi lapangan ijtihad sebagaimana dianjurkan oleh para pembaharu Islam. Hal ini disebabkan karena masalah aqidah, ibadah dan akhlak telah dinash secara jelas atas hukum-hukumnya, sebagai tujuan dari ubudiah. Begitu juga, ijtihad tidak diperbolehkan terhadap dasar-dasar syariat, prinsip-prinsip umum dan hukumhukumnya yang qath' $i$ seperti keharaman yang pasti; tanggung jawab individu; tidak adanya sanksi bebas atas dosa orang lainnya; saling rela dalam akad; soal jaminan rusak dan berbahaya; diperbolehkannya transaksi dagang dan diharamkannya riba; keabsahaan ikrar diri, bukan orang lain; prinsip tidak berbahaya dan membahayakan; prevensi terhadap jalan yang berdampak fasad; menjaga hak asasi; menggugurkan sanksi pidana subhat; kompetensi hak milik; keharaman berbuat zalim; penipuan, pemungutan dengan paksa; halalnya hewan-hewan yang disembelih yang boleh dimakan; haramnya bangkai, darah, daging babi dan hewan yang disembelih untuk selain Allah. ${ }^{13}$

\section{Sekilas Riwayat Hidup Buya Hamka}

Prof. DR. Hamka atau dikenal dengan panggilan akrabnya, Buya Hamka lahir di Sungai Batang Maninjau, Sumatera Barat, pada tanggal 17 Februari 1908/14 Muharram 1326 dan wafat di Jakarta pada 24 Juli 1981. Buya Hamka meninggalkan sepuluh orang anak, tujuh laki-laki dan tiga perempuan. Nama lengkap dari Buya Hamka adalah Haji Abdul Malik bin Haji Abdul Karim Amrullah. Ayahnya bernama Dr. Haji Abdul Karim Amrullah adalah

\footnotetext{
${ }^{13}$ Wahbah az-Zuhaili, al-Qur'an dan Paradigma., hlm.175.
}

seorang ulama terkenal pembawa paham pembaharuan Islam di Minangkabau yang sering disebut dengan tokoh kaum muda. Pada usia 6 tahun dia dibawa ayahnya ke Padang Panjang dan usia 7 tahun dia masuk sekolah desa dan malam harinya belajar mengaji al-Qur'an dengan ayahnya sendiri sampai khatam. ${ }^{14}$

Pendidikan yang ditempuh oleh Hamka muda setelah tamat dari sekolah desa adalah belajar di sekolah Diniyah School dan Sumatera Tawalib Padang Panjang dan Parabek. Guru-gurunya pada waktu itu antara lain Syeikh Ibrahim Musa Parabek, Engku Mudo Abdul Hamid, dan Zainuddin Labai. Kota Padang Panjang pada waktu itu ramai dikunjungi oleh para pelajar untuk belajar ilmu agama dibawah pimpinan ayah Hamka sehingga dikemudian hari kota Padang Panjang khususnya dan Minangkabau umumnya digelari dengan sebutan "Serambi Mekkah" kedua setelah Aceh.

Pada tahun 1924 Hamka berangkat ke Yogyakarta dan mulai mempelajari pergerakan Islam yang mulai marak dibawah asuhan HOS Tjokroaminoto, $\mathrm{H}$. Fachruddin, RM Suryopranoto dan iparnya sendiri Buya AR St Mansur. Dalam memoirnya Hamka menceritakan sendiri bahwa ada beberapa guru yang amat mempengaruhi jalan pikirannya dalam agama, sehingga ia dapat menciptakan buah pikiran, buku-buku, syair-syair, roman dan lain-lain. Saya tidak dapat melupakan nama-nama seperti Almarhum H. Fachroedin, K.H. Mas Mansur, H.O.S Tjokroaminoto, dan A.R. Sutan Mansur. Begitu juga Hamka tidak dapat melupakan perkenalannya dengan guru A. Hassan Bandung dan M. Natsir ketika ia pergi ke Bandung pada tahun 1929 dan ia juga diterima menjadi penulis dalam majalah

\footnotetext{
${ }^{14}$ Shalahuddin Hamid dan Iskandar Ahza, 100 Tokoh Islam Paling Berpengaruh Di Indonesia, (Jakarta: Intimedia, 2003), hlm.63.
} 
Pembela Islam. Kata Hamka waktu itu ia menulis tentang Islam dari ciptaan renungannya sendiri. ${ }^{15}$

Meskipun Hamka telah menjadi seorang yang terkenal namun ia tidak bisa lepas dari orang-orang besar yang mempengaruhi jalan berpikir hidupnya. Ada dua orang ulama besar yang mempengaruhi jalan hidupnya dan pengajaran-pengajarannya yang kemudian menjadi dasar dalam membentuk cara berpikirnya yaitu ayahnya sendiri, Dr H.A. Karim Amrullah dan kakak iparnya sendiri, A.R. Sutan Mansur. Untuk mengenal jasa besar dan perjuangan ayahnya Hamka menulis suatu buku tentang riwayat hidupnya dan diberi judul "Ayahku". Iparnya AR Sutan Mansur disebut oleh Hamka sebagai orang "khadam" dari kedua kitab yang senantiasa tidak tercerai dari dekatnya yaitu pertama al-Qur'an dan kedua kitab Fathur Rahman, pencari ayat al-Qur'an. ${ }^{16}$

Berdasarkan paparan di atas maka dapat dibuat geneologis Buya Hamka, yaitu:

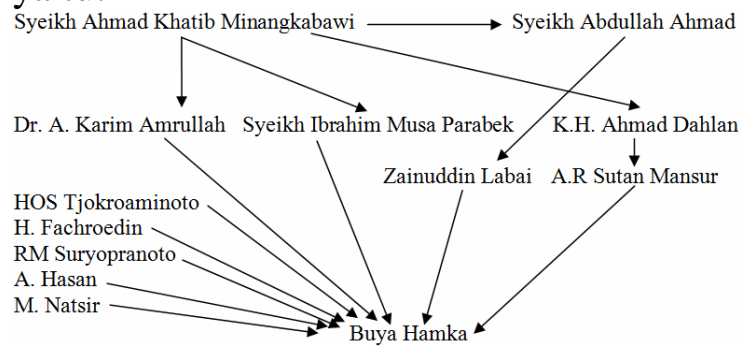

Pada tahun 1935 Hamka pulang ke Padang Panjang, bakat menulisnya mulai tampak dan ia pun juga sangat produktif menulis. Lebih dari 113 buah karya dari berbagai bidang lahir dari goresan tintanya. Bidang-bidang yang menjadi bahan tulisannya adalah kesusasteraan, sejarah, otobiografi, politik, tasawuf dan agama. Di antara buku-buku terkenal yang ditulisnya

\footnotetext{
${ }^{15}$ Hamka, Falsafah Hidup,(Jakarta: Pustaka Panjimas, 1994), hlm.1.

${ }^{16}$ Ibid.hlm. 2.
}

adalah Tenggelamnya Kapal Vanderwijck, Falsafah Hidup, Tasawuf Moderen, Perkembangan Tasawuf dari Abad ke Abad, Lembaga Hidup, Muhammadiyah Melalui Tiga Zaman, Empat Bulan di Amerika, Adat Minangkabau, Dibawah Lindungan Ka'bah, dan Pandangan Hidup Muslim.

Dalam karir kehidupan Buya Hamka terbilang cukup besar, baik kiprahnya di pentas nasional maupun internasional. Berbagai tanda jasa disematkan ke dirinya seperti pemberian gelar Doctor Honoris Causa oleh Universitas al-Azhar Cairo pada 10 Maret 1959 berkat keberhasilannya dalam penyiaran Islam dengan bahasa Indonesia yang baik dan indah dan oleh Universitas Kebangsaan malaysia di bidang kesusasteraan pada 8 Juni 1974. Sebelumnya pada 17 Mei 1966 Hamka juga diangkat sebagai Profesor Kehormatan oleh Universitas Prof. Dr. Moestopo. Berbagai pengakuan yang diperolehnya terutama dari Universitas yang paling tua di dunia diceritakan oleh Buya Hamka dalam suratnya kepada Solihin Salam yaitu berkat kekerasan hati dan penderitaan-penderitaan hidup yang dialaminya dalam hidupnya.

HAMKA aktif dalam gerakan Islam melalui organisasi Muhammadiyah. Beliau mengikuti pendirian Muhammadiyah mulai tahun 1925 untuk melawan khurafat, bid'ah, tarekat dan kebatinan sesat di Padan g Panjang. Mulai tahun 1928 beliau mengetuai cabang Muhammadiyah di Padang Panjang. Pada tahun 1929 HAMKA mendirikan pusat latihan pendakwah Muhammadiyah dan dua tahun kemudian beliau menjadi konsul Muhammadiyah di Makassar. Kemudian beliau terpilih menjadi ketua Majelis Pimpinan Muhammadiyah di Sumatera Barat oleh Konferensi Muhammadiyah, menggantikan S.Y. Sutan Mangkuto pada tahun 1946. Pada tahun 1953, HAMKA 
dipilih sebagai penasihat pimpinan Pusat Muhammadiyah.

\section{Pandangan Buya Hamka tentang Ijtihad dan Taqlid}

Pandangan Buya Hamka tentang ijtihad dilandasi oleh konsep yang dikemukakannya tentang kemerdekaan manusia (umat Islam) dalam menyatakan pikiran. Manusia bebas dan merdeka dalam menyatakan hasil pemikirannya yang telah matang dan diyakini keabsahannya. Dan suatu hasil pemikiran yang matang dan diyakini akan keabsahannya yang dinyatakan secara merdeka di hadapan umum kelak oleh orang lain akan merdeka pula membantah dengan pikiran pula. Manusia yang hendak menyatakan pikirannya dengan merdeka tersebut kata Buya Hamka harus menjaga "beberapa undang-undang", yang tidak keluar dari garis keadilan dan peraturan, dan tidak pula mengganggu kebebasan dan kemerdekaan orang lain.

Dalam Islam pintu kekebasan dalam menyatakan pikiran kata Buya Hamka adalah terbuka luas, "yaitu dengan kebebasan Ijtihad" ${ }^{17}$ Kemerdekaan berijtihad termasuk dalam rangka kebebasan berpikir dan kebebasan menyatakan pikiran. Kemajuan ilmu pengetahuan dalam Islam seperti dalam bidang Ushul Fiqh, Fiqh, Ilmu Tafsir, Ilmu Tasawuf dan lain-lain kata Buya Hamka "adalah berpangkal dari terbukanya pintu ijtihad" itu sendiri. Begitu juga dengan ulama-ulama besar yang telah mendirikan empat mazhab fiqh dalam Islam kata Buya Hamka juga "adalah bersumber dari kebebasan ijtihad". Dengan demikian, kehidupan umat Islam dan kemajuannya di berbagai bidang di zaman sekarang ini menurut Buya Hamka adalah "amat bergantung kepada kemerdekaan berpikir (berijtihad) dan kemerdekaan menyatakan

\footnotetext{
${ }^{17}$ Hamka, Falsafah Hidup., hlm. 268.
}

hasil fikiran itu". ${ }^{18}$ Adapun penyebab terbesar dari terjadinya kemunduran pemikiran dalam Islam, sehingga muncul paham jumud (membeku) dan statis dalam pandangan Buya Hamka adalah "setelah timbul pendapat di abad ketujuh Hijriyah bahwa pintu ijtihad telah tertutup dan kita lebih baik taqlid saja". ${ }^{19}$

Dari pernyataan-pernyataan Buya Hamka di atas dapat ditarik suatu kesimpulan bahwa yang dimaksud dengan ijtihad olehnya adalah suatu hasil pemikiran setelah matang dipikirkan dan diyakini. Pengertian ijtihad yang dibuat oleh Buya Hamka tersebut bersumber dan dilandasi dari hadits Nabi yang berarti, "Barang siapa yang berijtihad, lalu benar hasil ijtihadnya, mendapatlah dia dua pahala. Dan barang siapa yang berijtihad, tetapi tidak tepat hasil ijtihadnya mendapat dia satu pahala”. Adapun yang dimaksud dengan mendapat dua pahala dalam hadits ini adalah pertama pahala ijtihad, yaitu kemampuan seseorang dalam mencurahkan daya upayanya untuk memperoleh suatu hasil pemikiran yang matang dan diyakini dan kedua pahala benar hasil ijtihad (pemikiran) nya. Sedangkan mendapat satu pahala bermaksud yaitu pahala dari ijtihad yang dilakukan. Dengan demikian kata Buya Hamka "tidak berdosa kalau salah hasil ijtihadnya itu, karena ia berijtihad mencari kebenaran sedangkan kesalahan terjadi tanpa sengaja". ${ }^{20}$

Sangat menarik sekali jika diperhatikan kitab-kitab fiqh lama yang ditulis pada masa klasik dan abad pertengahan di dalamnya mengemukakan suatu pendapat dan pengarangnya selalu tidak lupa mengemukakan pendapat dari ulama-ulama lain, yang berbeda paham

\footnotetext{
${ }^{18}$ Ibid. hlm. 270.

${ }^{19}$ Ibid. hlm. 269.

${ }^{20}$ Ibid. hlm. 269.
} 
dengan dia, sehingga para membaca atau yang mempelajari dapat membandingkan pendapat-pendapat itu. Berdasarkan dalil yang dikemukakan oleh Buya Hamka dalam mengutarakan maksudnya tentang ijtihad maka dapat dikatakan bahwa pengertian ijtihad yang dikemukannya selaras dengan berbagai pengertian ijtihad yang dibuat oleh para ulama ushul figh di atas, di antaranya yaitu dengan mencurahkan kemampuan maksimal dalam upaya menggali hukum-hukum syara'.

Landasan seseorang dalam berijtihad adalah al-Qur'an dan as-Sunnah. Keduanya adalah sumber pokok dari ajaran Islam. Buya Hamka juga meyakini kedua sumber pokok ajaran Islam yang dijadikan landasan dalam berijtihad dengan menyatakan "sumber telaga ijtihad tetap pada dua, yaitu al-Qur'an dan as-Sunnah. Ini disepakati oleh orang dahulu dan oleh orang sekarang". ${ }^{21}$ Al-Qur'an yang menjadi panutan Nabi Muhammad SAW dan orang-orang sesudahnya ia merupakan sumber pokok (primer) syariat Islam, di dalamnya dijelaskan tentang dasar-dasar syariat, akidah-akidah secara terperinci, dan ibadah serta peradilan secara global. Posisi al-Qur'an dalam syariat Islam seperti posisi undang-undang dalam hukum positif. Misalnya, secara global alQur'an menjelaskan shalat dan zakat dan tidak menerangkan tentang tata cara dan batasan-batasannya. Tata cara serta batasan-batasan shalat dan zakat diterangkan oleh Sunnah Nabi Muhammad SAW. Sedangkan Sunnah merupakan sumber tasyri' berada setingkat di bawah al-Qur'an. Sunnah sebagai penjelas keglobalan dan kemusykilan (kerumitan) al-Qur'an, pentasdddqyid (pembatas)

\footnotetext{
${ }^{21}$ Ibid. hlm. 270.
}

kemutlakan (keumuman) al-Qur'an dan menjelaskan apa yang belum terdapat dalam al-Qur' an. ${ }^{22}$

Seseorang yang telah memiliki hasil pemikiran yang matang dan diyakini juga akan kesahihannya memerlukan wadah sebagai tempat untuk menuangkannya. Wadah yang terutama menjadi tempat penuangan pemikiran yang telah matang tersebut kata Buya Hamka adalah "dalam surat-surat kabar dan buku-buku”. ${ }^{23}$ Dengan demikian, para penulis merupakan orang yang pertama kali mendapat kesempatan dalam kemerdekaan berpikir tersebut. Akan tetapi sebagai sebuah hukum alam bahwa kemerdekaan seseorang juga dibatasi oleh kemerdekaan orang lain. Dengan demikian kemerdekaan berpikir itu ada batas dan syarat-syaratnya, yaitu "jangan keluar dari garis adab dan sopan walaupun hal yang benar yang akan diterangkan". Di samping itu, seorang yang menyatakan hasil pemikirannya seyogianya pula ia "sanggup mempertahankan keyakinan dan hujjahnya, lagi luas pandangannya serta mengetahui hakikat perkara yang ditulisnya".

Dalam menulis seseorang harus menjaga etika berlaku adil dan jujur serta tidak boleh membuat tulisan-tulisan yang bersifat dusta dan menipu. Begitu juga seseorang tidak boleh menulis sesuatu yang tidak berdasarkan atas kebenaran karena jika dilakukan kata Buya Hamka, "walaupun mula-mula ditelan orang, namun zaman kelak akan memuntahkan "kebenaran celupan" dari perut orang yang telah terlanjur menelannya". Lawan dari istilah "ijtihad" adalah "taqlid". Orang yang melakukan taqlid disebut dengan muqallid. Taqlid yaitu memperpegangi

\footnotetext{
${ }^{22}$ Mustahafa Ahmad al-Zarqa, Hukum Islam dan Perubahan Sosial, terjemahan Ade Dedi Rohayana, (Jakarta: Riora Cipta, 2000), hlm. 4.

${ }^{23}$ Hamka, Falsafah Hidup., hlm. 270.
} 
pendapat orang lain tanpa mengetahui dalil-dalilnya. Dalam artian lain dikatakan bahwa taqlid adalah menerima pendapat orang lain tanpa ada hujjah atau seseorang menerima pendapat orang lain dan ia tidak mengetahui dari mana sumber pengambilan pendapat yang diikutinya. Seorang muqallid (pengikut saja) hanya akan menurut saja akan apa yang dikatakan oleh orang diikutinyanya. Wahbah azZuhaili menyatakan bahwa taqlid adalah memperpegangi mazhab lain tanpa mengenal dalilnya. ${ }^{24}$ Adapun memperpegangi atau menerima pendapat (mazhab) orang lain serta mengenal dan memahami akan dalil-dalilnya (hujjah) maka tidak disebut dengan taqlid tetapi adalah suatu ijtihad yang menyesuai akan ijtihad orang lain yang diikutinya karena mengenal dan memahami dalil itu hanyalah kerja dari seorang mujtahid. ${ }^{25}$

Para ulama yang menjadi pembela taqlid setelah terjadinya penutupan pintu ijtihad kata Buya Hamka mengemukakan suatu dalil pendapat yaitu "orang yang telah terdahulu, tidak meninggalkan lagi untuk orang-orang kemudian soal-soal yang akan dibicarakan". Pendapat ini bertujuan untuk mengukuhkan dan menumbuh suburkan akan budaya taqlid dalam Islam, suatu budaya yang sangat ditentang dan kurang terpuji. Namun, jika seseorang tidak mampu mengenal akan dalil maka sebaiknya ia mengikuti akan suatu ijtihad yang diyakini akan kesahihannya.

\section{E. Penutup}

Pandangan Buya Hamka tentang ijtihad dilandasi oleh prinsip-prinsip yang terkandung dalam Ushul Fiqh. Buya 355.

${ }^{24}$ Wahbah az-Zuhaili, al-Wajiz., Jilid II, hlm.

25 Ahmad Kahtib al-Minangkawbawi, anNafahat 'ala Syarh al-Waraqat, (Indonesia: Haramain, 2006), hlm. 162.
Hamka meyakini bahwa sumber telaga ijtihad yang menjadi rujukan bagi ahli ijtihad adalah al-Qur'an dan Sunnah. Kedua sumber ini telah disepakati oleh para ahli hukum Islam sejak dahulu, sekarang, bahkan hingga nanti. Kemerdekaan berpikir (ijtihad) sangat besar pengaruhnya bagi kemajuan masyarakat (umat Islam sendiri). Sebab, apabila suatu pendapat telah dikeluarkan, kelak ia akan mendapat bandingan dari yang lain, sehingga nyata yang benar dan yang salah. Meskipun suatu hasil pemikiran yang matang dan diyakini kesahihannya (suatu hasil ijtihad) tetaplah ia bersifat relatif dan orang lain bebas pula tidak taqlid (menurut saja) kepada hasil ijtihad tersebut, apalagi kepada hasil ijtihad yang salah atau keliru yang hanya mendapatkan satu pahala saja.

\section{DAFTAR PUSTAKA}

Abu Zahrah, Muhammad, Ushul Fiqh, (Beirut; Dar al-Fikr, 1976)

al-Amidi, Saifuddin Abi Hasan Ali bin Muhammad, Mustaha Shul fi Ilmi Ushul, (Beirut: Dar al-Kutub alIlmiyah, 2002)

al-Asnawi, Jamaluddin Abd Rahman, Syarh al-Asnawi Syarh Minhaj alWusul fi Ilmi Ushul, (Mesir: Muhammad Ali Subaih, t.t.)

Ibn Mundzir, Jamaluddin Muhammad, Lisan al-Arab, Juz III, (Mesir: Dar al-Mishriyyah at-Ta'lif wa atTarjamah, t.t.),

Hamid, Shalahuddin dan Iskandar Ahza, 100 Tokoh Islam Paling Berpengaruh Di Indonesia, (Jakarta: Intimedia, 2003)

Hamka, Falsafah Hidup, (Jakarta: Pustaka Panjimas, 1994) 
'Isa, Abd al-Jalil, Ijtihad ar-Rasul Salla Allah 'alaihi Wasallam, (Beirut: Dar al-Bayyan, 1969)

Kholid, Ahmad, Melacak Sejarah Metodologi Ijtihad, (Bandung:Sahifa, 2009)

Al-Minangkawbawi, Ahmad Kahtib, anNafahat 'ala Syarh al-Waraqat, (Indonesia : Haramain, 2006)

asy-Syaukani, Muhammad, Irsyad alFuhul, (Beirut: Dar al-Ihya at-Turas al-Arabi, t.t.)
al-Zarqa, Mustahafa Ahmad, Hukum Islam dan Perubahan Sosial, terjemahan Ade Dedi Rohayana, (Jakarta: Riora Cipta, 2000)

az-Zuhaili, Wahbah, al-Qur'an, Paradigma Hukum dan Peradaban, terjemahan Muhammad Lukman Hakim dan Muhammad Fuad Hariri, (Surabaya, Risalah Gusti, 1995)

al-Wajiz fi Ushul Fiqh Islami, Juz.II, (Beirut: Dar al-Khair, 2006) 